University of Nebraska - Lincoln

DigitalCommons@University of Nebraska - Lincoln

Faculty Papers and Publications in Animal

Science

Animal Science Department

1997

\title{
Limiting Amino Acids in Meat and Bone and Poultry By-Product Meals
}

\author{
M. J. Klemesrud \\ University of Nebraska-Lincoln \\ Terry Klopfenstein \\ University of Nebraska-Lincoln, tklopfenstein1@unl.edu \\ Austin Lewis \\ University of Nebraska-Lincoln, alewis2@unl.edu \\ D. H. Shain \\ University of Nebraska-Lincoln \\ D. Herold \\ University of Nebraska-Lincoln
}

Follow this and additional works at: https://digitalcommons.unl.edu/animalscifacpub

Part of the Animal Sciences Commons

Klemesrud, M. J.; Klopfenstein, Terry; Lewis, Austin; Shain, D. H.; and Herold, D., "Limiting Amino Acids in Meat and Bone and Poultry By-Product Meals" (1997). Faculty Papers and Publications in Animal Science. 524.

https://digitalcommons.unl.edu/animalscifacpub/524

This Article is brought to you for free and open access by the Animal Science Department at DigitalCommons@University of Nebraska - Lincoln. It has been accepted for inclusion in Faculty Papers and Publications in Animal Science by an authorized administrator of DigitalCommons@University of Nebraska - Lincoln. 


\title{
Limiting Amino Acids in Meat and Bone and Poultry By-Product Meals ${ }^{1}$
}

\author{
M. J. Klemesrud, T. J. Klopfenstein², A. J. Lewis, D. H. Shain, and D. W. Herold \\ Department of Animal Science, University of Nebraska, Lincoln 68583-0908
}

\begin{abstract}
In situ, digestion, and growth studies were conducted to evaluate four meat and bone meals and six poultry by-product meals as sources of escape protein and to predict the first-limiting amino acid for growing calves. Escape protein values, determined by $12-\mathrm{h}$ in situ incubation, ranged from 41.7 to $51.0 \%$ of CP for meat and bone meals; poultry by-product meals ranged from 32.0 to $39.8 \%$. True protein digestion in the gastrointestinal tract of lambs differed among protein sources $(P<.05)$, ranging from 79 to $95 \%$. In each of three growth trials, 60 steers ( $258 \pm 24,241 \pm$ 23, and $230 \pm 16 \mathrm{~kg}$ for Trials 1, 2, and 3, respectively) were supplemented with 4 of the 10 protein sources along with a urea supplement. Protein sources were fed at $30,40,50$, and $60 \%$ of the supplemental CP,
\end{abstract}

with urea supplying the remainder. Protein efficiency differed among treatments $(P<.10)$, ranging from .61 to 1.55. Amino acid composition was determined for each protein source, and the individual metabolizable amino acids were regressed on the protein efficiency values. Escape protein values were correlated $\left(R^{2}=\right.$ .75) with protein efficiency but had a negative slope. Metabolizable methionine was the only amino acid moderately correlated $\left(R^{2}=.40\right.$, slope $\left.=1.9\right)$ to protein efficiency, whereas other amino acids either correlated poorly or had negative slopes. These data indicate that the protein value of meat and bone meal and poultry by-product meal is limited by the amount of metabolizable methionine they contain.

Key Words: Meat and Bone Meal, By-Products, Protein, Amino Acids, Methionine, Beef Cattle

J. Anim. Sci. 1997. 75:3294-3300

\section{Introduction}

Meat and bone meal (MBM) and poultry byproduct meal (PBM) are rendered animal byproducts that are potential sources of escape protein for ruminants. However, using MBM as an escape protein source has had variable results (Stock et al., 1981). Meat and bone meal varies in ruminal escape protein, amino acid composition, and amino acid availability (Knabe et al., 1989; Gibb et al., 1991). This may be the result of heat damage during rendering (Leibholz, 1979; Batterham and Darnell, 1986; Knabe et al., 1989) and(or) the type of tissues rendered (Eastoe and Long, 1960; Atkinson and Carpenter, 1970). Gibb et al. (1991) reported higher escape protein values for MBM made from bones than MBM made from viscera or deadstock. Generally, bone decreases protein content and decreases the amount of essential amino acids (K nabe et al., 1989; Gibb et al., 1991).

\footnotetext{
${ }^{1}$ Published with the approval of the director as paper no. 11614, journal series, Nebraska Agric. Res. Div.

${ }^{2}$ To whom correspondence should be addressed.

Received December 11, 1996.

Accepted J uly 18, 1997.
}

This research was conducted to evaluate a variety of MBM and PBM products as sources of escape protein for growing calves. Escape protein, CP digestibility, and ash content of these products were evaluated as predictors of protein efficiency, and the firstlimiting amino acid in MBM and PBM was predicted.

\section{Materials and Methods}

Four samples of MBM and six samples of PBM were obtained from commercial renderers across the United States. Products were selected to be variable in composition and represent the variety of products available on the market.

In Situ Study. Samples of MBM and PBM were incubated in situ to determine escape protein (Wilkerson et al., 1995). Approximately $4 \mathrm{~g}$ of each protein source was placed in each of four Dacron ${ }^{\circledR}$ bags ( $10 \times$ $20 \mathrm{~cm} ; 50-\mu \mathrm{m}$ pore size; du Pont, Wilmington, DE ). Each bag was sealed by wrapping the top around a \#8 rubber stopper and secured with a \#18 rubber band. The bag was then folded over the rubber band and a second rubber band was added. Sample bags were placed in four polyester bags $36 \times 42 \mathrm{~cm}$ made of mesh material and closed with a nylon zipper. To facilitate 
Table 1. Basal diet for the lamb digestion trial

\begin{tabular}{lc}
\hline \hline Ingredient & $\%$, DM \\
\hline Ensiled corncobs & 72.70 \\
Alfalfa pellets & 15.00 \\
Ground corn & 10.00 \\
Urea & 1.48 \\
Dicalcium phosphate & .26 \\
Salt & .30 \\
Ammonium sulfate & .17 \\
Trace minerals & $.04^{\mathrm{a}}$ \\
Vitamins & $.03^{\mathrm{b}}$ \\
Selenium & $.02^{\mathrm{c}}$ \\
\hline
\end{tabular}

${ }^{\mathrm{a} C}$ Contains $10 \% \mathrm{Mg}, 6 \% \mathrm{Zn}, 4.5 \% \mathrm{Fe}, 2 \% \mathrm{Mn}, .5 \% \mathrm{Cu}$, and .3\% I. b 15,000 IU vitamin A, 3,000 IU vitamin D, and 3.75 IU vitamin E per gram of premix.

'Premix contains $.06 \%$ Se.

hydration, all bags were soaked in $39^{\circ} \mathrm{C}$ water for 20 min before ruminal incubation. Two nylon bags were placed in the liquid phase of the ruminal ventral sac of each of two mature ruminally cannulated crossbred steers $(534 \mathrm{~kg})$ maintained on a grass hay diet.

Following $12 \mathrm{~h}$ of ruminal incubation (Wilkerson et al., 1993), bags were removed from the rumen and washed by hand until the rinse water was clear. Total N (AOAC, 1975) was determined before and after ruminal incubation to estimate the amount of ruminal escape protein for each source without correction for microbial attachment. Protein sources were additionally analyzed for ash content (AOAC, 1975).

Residue remaining after incubation was composited by protein source and analyzed for amino acid content along with the original protein source. Samples were hydrolyzed in $6 \mathrm{~N} \mathrm{HCl}$, and amino acid content of hydrolyzates was determined by ion-exchange chromatography (AOAC, 1975). Separate samples were oxidized with performic acid for analysis of cystine and methionine (AOAC, 1975). A separate analysis for tryptophan was also conducted using the procedure of Lewis et al. (1976) modified for manual analysis. All analyses were conducted in duplicate.

The GLM procedure of SAS (1985) was used to analyze the protein degradation data. The experiment was of a completely randomized design, and the statistical model included protein source and error. Least significant differences (SAS, 1985) were used to separate treatment means. For each amino acid, concentration was compared before and after ruminal digestion using means comparison and Pearson Correlation Analysis (SAS, 1985).

Digestion Study. Twenty-four crossbred wether lambs (31.8 $\pm 3.6 \mathrm{~kg})$ housed in individual metabolism crates were fed a basal diet (Table 1 ) containing ensiled corncobs and alfalfa pellets. The basal diet was fed to all lambs at $1.9 \%$ of BW (DM basis) throughout the trial. This maintenance diet was balanced to provide a minimum of $10 \% \mathrm{CP}, 52 \%$ TDN, .42\% Ca, and .18\% P. Urea was included in the basal diet to ensure that rumen $\mathrm{NH}_{3}$ was not limiting digestion and provided $44 \%$ of the basal dietary CP.

The study consisted of three periods, each containing a 14-d adaptation period and a 7-d fecal collection period. Within each period, lambs were assigned randomly to treatment protein; two lambs were assigned to each of the 10 protein sources, soybean meal (SBM), or an unsupplemented control. Lambs were rerandomized to treatment protein between periods. Supplemental protein sources were fed at $3.75 \%$ of the basal diet DMI as units of additional CP. Therefore, the supplemental DMI in addition to the basal diet was dependent on the CP content of the treatment protein source. All diets containing treatment proteins were isonitrogenous and contained $13.75 \% \mathrm{CP}$, and the unsupplemented control diet contained $10 \%$ CP. Treatment protein sources were individually weighed and hand-mixed into the basal diet at the time of feeding.

Lambs were weighed before the trial to enable feeding of diets on an equal percentage of BW. Lambs were fitted with fecal collection bags to allow for total fecal collection. Feces was collected daily and weighed, and a $10 \%$ subsample was taken. Subsamples were composited by lamb for the 7-d collection period. Feed, feces, and orts were oven-dried $\left(60^{\circ} \mathrm{C}\right)$ and analyzed for DM and CP content (AOAC, 1975). True protein digestibility was calculated by difference from unsupplemented-control sheep as outlined by Blasi et al. (1991). Results were analyzed as a randomized complete block design using the GLM procedure of SAS (1985) with the model containing protein source, period, and source $\times$ period interaction. Least significant differences (SAS, 1985) were used to separate treatment means.

Growth Trials. In each of three growth studies, diets of $44 \%$ sorghum silage ( $7.1 \% \mathrm{CP}, 68 \%$ TDN), $44 \%$ corncobs $(2.3 \% \mathrm{CP}, 48 \%$ TDN ), and $12 \%$ supplement (DM basis, Tables 2, 3, and 4) were individually fed to 60 crossbred steer calves $(258 \pm 24,241 \pm 23$, and $230 \pm 16 \mathrm{~kg}$ for Trials 1, 2, and 3, respectively). Steers were supplemented with 4 of the 10 protein sources along with a urea control in each of the three studies. Trials 2 and 3 included a replicated protein source from the previous trial so that protein sources could be compared across trials. If the protein efficiency of the replicated protein source was not statistically different between the two trials, protein efficiencies were combined for analysis.

Protein sources were fed to supply $30,40,50$, or $60 \%$ of the supplemental $N$, with urea supplying the remainder. Therefore, regardless of the assigned level, all steers consumed a diet containing $11.0 \%$ CP (DM basis). Steers were assigned randomly to treatment and level of treatment protein with 12 steers per treatment and three steers per level. Steers were individually fed, at an equal percentage of body weight, once daily with Calan electronic gates (American Calan, Northwood, $\mathrm{NH}$ ). The percentage of body 
KLEMESRUD ET AL.

Table 2. Supplement composition for growth Trial $1^{\text {a }}$

\begin{tabular}{lccccc}
\hline \hline & \multicolumn{5}{c}{ Treatment } \\
\cline { 2 - 5 } Ingredient & Urea & MBM 1 $^{\mathrm{b}}$ & MBM2 $^{\mathrm{b}}$ & MBM 3 $^{\mathrm{b}}$ & PBM $^{\mathrm{b}}$ \\
\hline Meat and bone meal 1 & - & 71.06 & - & - & - \\
Meat and bone meal 2 & - & - & 50.32 & - & - \\
Meat and bone meal 3 & - & - & - & 50.32 & - \\
Poultry by-product meal & - & - & - & - & 42.66 \\
Soyhulls & 71.64 & 16.97 & 37.71 & 37.71 & 45.37 \\
Urea & 16.16 & 7.00 & 7.00 & 7.00 & 7.00 \\
Dicalcium phosphate & 7.23 & - & - & - & - \\
Salt & 2.50 & 2.50 & 2.50 & 2.50 & 2.50 \\
Ammonium sulfate & 1.67 & 1.67 & 1.67 & 1.67 & 1.67 \\
Trace minerals & .42 & .42 & .42 & .42 & .42 \\
Vitamins $^{\mathrm{d}}$ & .25 & .25 & .25 & .25 & .25 \\
Selenium $^{\mathrm{e}}$ & .13 & .13 & .13 & .13 & .13 \\
\hline
\end{tabular}

a Values are expressed as percentage of DM; supplement was fed at $12 \%$ of DMI

bSupplements that were mixed with urea supplement to supply $30,40,50$, or $60 \%$ of supplemental protein.

${ }^{\mathrm{c}} 10 \% \mathrm{Mg}, 6 \% \mathrm{Zn}, 4.5 \% \mathrm{Fe}, 2 \% \mathrm{Mn}, .5 \% \mathrm{Cu}, .3 \% \mathrm{I}, .05 \% \mathrm{Co}$.

$\mathrm{d}_{30,000} \mathrm{IU}$ of vitamin $\mathrm{A}, 6,000 \mathrm{IU}$ of vitamin $\mathrm{D}$, and $7.5 \mathrm{IU}$ of vitamin $\mathrm{E}$ per gram of premix.

epremix contained $.06 \%$ Se.

weight fed was adjusted as needed to minimize orts while maintaining intake near ad libitum. Average intake was $2.1,2.3$, and $2.1 \%$ of body weight for Trials 1,2 and 3 , respectively.

Weight data were collected before feeding on three consecutive days at the beginning and end of each 84-d trial. Efficiency of protein utilization was determined for each protein source using the sloperatio technique (Klopfenstein et al., 1985) with the ureasupplemented steers as the control. Protein efficiencies, calculated as the units of gain obtained greater than the control steers per unit of protein consumed greater than the control diet, were determined for each treatment using the NLIN procedure of SAS (1985). Slopes (protein efficiencies) were compared using a two-tailed t-test (Steel and Torrie, 1980).

In situ escape protein data, amino acid degradation data, and true CP digestibility data were used to calculate the amount of each metabolizable amino acid supplied from each protein source (Wilkerson et al., 1993). To determine the first-limiting amino acid, metabolizable amino acid supplies were regressed (SAS, 1985) on protein efficiency values. Escape protein, CP digestibility, and ash content values were also regressed on protein efficiency to determine their ability in predicting protein efficiency.

Table 3. Supplement composition for growth Trial $2^{\mathrm{a}}$

\begin{tabular}{|c|c|c|c|c|c|}
\hline \multirow[b]{2}{*}{ Ingredient } & \multicolumn{5}{|c|}{ Treatment } \\
\hline & Urea & $\mathrm{PBM} 1^{\mathrm{b}}$ & $\mathrm{PBM} 2^{\mathrm{b}}$ & PBM $3^{b}$ & PBM $4^{b}$ \\
\hline Poultry by-product meal 1 & - & 42.66 & - & - & - \\
\hline Poultry by-product meal 2 & - & - & 44.67 & - & - \\
\hline Poultry by-product meal 3 & - & - & - & 41.23 & - \\
\hline Poultry by-product meal 4 & - & - & - & - & 49.91 \\
\hline Soyhulls & 71.64 & 45.37 & 43.36 & 46.80 & 38.12 \\
\hline Urea & 16.16 & 7.00 & 7.00 & 7.00 & 7.00 \\
\hline Dicalcium phosphate & 7.23 & - & - & - & - \\
\hline Salt & 2.50 & 2.50 & 2.50 & 2.50 & 2.50 \\
\hline Ammonium sulfate & 1.67 & 1.67 & 1.67 & 1.67 & 1.67 \\
\hline Trace minerals ${ }^{c}$ & .42 & .42 & .42 & .42 & .42 \\
\hline Vitamins $^{d}$ & .25 & .25 & .25 & .25 & .25 \\
\hline Selenium ${ }^{\mathrm{e}}$ & .13 & .13 & .13 & .13 & .13 \\
\hline
\end{tabular}

aValues are expressed as percentage of DM; supplement was fed at $12 \%$ of DMI.

bSupplements that were mixed with urea supplement to supply $30,40,50$, or $60 \%$ of supplemental protein.

${ }^{\mathrm{c}} 10 \% \mathrm{Mg}, 6 \% \mathrm{Zn}, 4.5 \% \mathrm{Fe}, 2 \% \mathrm{Mn}, .5 \% \mathrm{Cu}, .3 \% \mathrm{I}, .05 \% \mathrm{Co}$.

d 30,000 IU of vitamin A, 6,000 IU of vitamin D, and 7.5 IU of vitamin E per gram of premix.

epremix contained $.06 \%$ Se. 
Table 4. Supplement composition for growth Trial $3^{a}$

\begin{tabular}{lccccc}
\hline \hline & \multicolumn{5}{c}{ Treatment } \\
\cline { 2 - 5 } Ingredient & Urea & PBM 4 $^{\mathrm{b}}$ & PBM 5 $^{\mathrm{b}}$ & PBM 6 $^{\mathrm{b}}$ & MBM 4 $^{\text {b }}$ \\
\hline Poultry by-product meal 4 & - & 49.91 & - & - & - \\
Poultry by-product meal 5 & - & - & 52.69 & - & - \\
Poultry by-product meal 6 & - & - & - & 54.98 & - \\
Meat and bone meal 4 & - & - & - & - & 52.58 \\
Soyhulls & 71.64 & 38.12 & 35.34 & 33.05 & 35.45 \\
Urea & 16.16 & 7.00 & 7.00 & 7.00 & 7.00 \\
Dicalcium phosphate & 7.23 & - & - & - & - \\
Salt & 2.50 & 2.50 & 2.50 & 2.50 & 2.50 \\
Ammonium sulfate & 1.67 & 1.67 & 1.67 & 1.67 & 1.67 \\
Trace mineralsc & .42 & .42 & .42 & .42 & .42 \\
Vitamins $^{\mathrm{c}}$ & .25 & .25 & .25 & .25 & .25 \\
Selenium $^{\mathrm{e}}$ & .13 & .13 & .13 & .13 & .13 \\
\hline
\end{tabular}

aValues are expressed as percentage of DM; supplement was fed at $12 \%$ of DMI.

bSupplements that were mixed with urea supplement to supply $30,40,50$, or $60 \%$ of supplemental protein.

${ }^{\mathrm{c}} 10 \% \mathrm{Mg}, 6 \% \mathrm{Zn}, 4.5 \% \mathrm{Fe}, 2 \% \mathrm{Mn}, .5 \% \mathrm{Cu}, .3 \% \mathrm{I}, .05 \% \mathrm{Co}$.

$\mathrm{d}_{30,000} \mathrm{IU}$ of vitamin $\mathrm{A}, 6,000 \mathrm{IU}$ of vitamin $\mathrm{D}$, and $7.5 \mathrm{IU}$ of vitamin $\mathrm{E}$ per gram of premix.

epremix contained $.06 \%$ Se.

\section{Results and Discussion}

In Situ Study. After $12 \mathrm{~h}$ of ruminal incubation, escape protein values differed $(P<.05)$, ranging from 32.0 to $51.0 \%$ of the CP escaping ruminal degradation (Table 5). Meat and bone meal sources ranged from 41.7 to $51.0 \%$ of the CP escaping ruminal degradation, whereas PBM sources ranged from 32.0 to $39.8 \%$. Crude protein ranged from 45.0 to $67.9 \%$, and percentage ash ranged from 12.3 to $40.5 \%$. Crude protein was negatively correlated to ash content $\left(R^{2}=\right.$ .72; slope $=-1.01$ ) because soft tissue is higher in CP than bone. Escape protein, however, was positively correlated with ash content $\left(\mathrm{R}^{2}=.51\right.$; slope $\left.=.58\right)$, indicating greater escape values for MBM and PBM

Table 5. Crude protein, escape protein ${ }^{a}$, and ash content of meat and bone meals and poultry by-product meals

\begin{tabular}{|c|c|c|c|}
\hline Item & $\begin{array}{c}\text { Crude } \\
\text { protein, \% N }\end{array}$ & escape, \% & Ash, \% \\
\hline Meat and bone meal 1 & 45.0 & $51.0^{\mathrm{b}}$ & 40.5 \\
\hline Meat and bone meal 2 & 58.5 & $45.2^{\mathrm{bc}}$ & 24.7 \\
\hline Meat and bone meal 3 & 58.4 & $44.3^{C}$ & 30.4 \\
\hline Meat and bone meal 4 & 56.1 & $41.7^{c}$ & 25.3 \\
\hline Poultry by-product meal 1 & 66.0 & $34.3^{\text {de }}$ & 16.3 \\
\hline Poultry by-product meal 2 & 63.4 & $39.8^{\mathrm{cd}}$ & 19.8 \\
\hline Poultry by-product meal 3 & 67.9 & $38.7^{\mathrm{cd}}$ & 12.3 \\
\hline Poultry by-product meal 4 & 58.5 & 33.9 de & 22.0 \\
\hline Poultry by-product meal 5 & 56.3 & $32.0^{e}$ & 24.0 \\
\hline Poultry by-product meal 6 & 53.5 & $32.0^{\mathrm{e}}$ & 19.3 \\
\hline SE & - & 2.0 & - \\
\hline
\end{tabular}

${ }^{\mathrm{a}}$ Expressed as a percentage of $\mathrm{CP}$ remaining after 12-h incubation in situ.

b,c,d,eValues within a column with unlike superscripts differ $(P<$ .05). made from bone than when made from soft tissue. This is in agreement with the findings of Gibb et al. (1991), in which CP was lower but escape values were higher for MBM made from bones than when it was made from viscera or deadstock.

Ruminal incubation of these protein sources increased essential amino acid concentration $(P<.05)$ as a ratio of the $\mathrm{CP}$ escaping ruminal degradation (Table 6), with the exception of tryptophan, which decreased in concentration. This decrease in tryptophan, also observed by Goedeken et al. (1990), suggests preferential degradation of tryptophan in the rumen. The increase in concentration of other essen-

Table 6. Amino acid composition ${ }^{\mathrm{a}}$ of meat and bone meal and poultry by-product meal sources before and after 12 hours of ruminal in situ incubation

\begin{tabular}{llll}
\hline \hline $\begin{array}{l}\text { Amino } \\
\text { acid }\end{array}$ & $\begin{array}{c}\text { Before 12-h } \\
\text { incubation }\end{array}$ & $\begin{array}{l}\text { After 12-h } \\
\text { incubation }\end{array}$ & $\mathrm{r}^{\mathrm{b}}$ \\
\hline Arg & $6.67 \pm .56$ & $7.40 \pm .73^{\mathrm{c}}$ & .40 \\
$\mathrm{His}$ & $1.60 \pm .13$ & $1.65 \pm .25$ & .35 \\
Ile & $2.34 \pm .26$ & $2.75 \pm .48^{\mathrm{c}}$ & .75 \\
Leu & $5.63 \pm .38$ & $6.70 \pm .67^{\mathrm{c}}$ & .01 \\
Lys & $4.80 \pm .41$ & $5.16 \pm .74$ & .64 \\
Met & $1.30 \pm .23$ & $1.48 \pm .40^{\mathrm{c}}$ & .97 \\
Phe & $3.11 \pm .18$ & $3.59 \pm .45^{\mathrm{c}}$ & .33 \\
Thr & $3.36 \pm .28$ & $3.94 \pm .44^{\mathrm{c}}$ & .40 \\
Trp & $.45 \pm .09$ & $.37 \pm .09^{\mathrm{c}}$ & .38 \\
Val & $3.23 \pm .15$ & $3.77 \pm .25^{\mathrm{c}}$ & .37 \\
Cys & $1.00 \pm .25$ & $1.48 \pm .46^{\mathrm{c}}$ & .23 \\
\hline
\end{tabular}

${ }^{a}$ Expressed as a percentage of CP before or after 12 -h ruminal in situ incubation.

bPearson correlation coefficient for amino acid before and after 12-h incubation.

CAmino acid content after 12 -h incubation differs from content before incubation $(P<.05)$. 
Table 7. Crude protein digestibility of test proteins by lambs

\begin{tabular}{lcc}
\hline \hline & $\begin{array}{c}\text { Apparent } \\
\text { diet }\end{array}$ & $\begin{array}{c}\text { True } \\
\text { CP }\end{array}$ \\
Item & $\begin{array}{c}\text { CP } \\
\text { CP }\end{array}$ \\
\hline Unsupplement \\
Soybean meal & $69.3^{\mathrm{b}}$ & - \\
Meat and bone meal 1 & $77.1^{\mathrm{e}}$ & $95.4^{\mathrm{b}}$ \\
Meat and bone meal 2 & $75.5^{\text {cde }}$ & $88.0^{\mathrm{bc}}$ \\
Meat and bone meal 3 & $73.4^{\mathrm{c}}$ & $79.1^{\mathrm{c}}$ \\
Meat and bone meal 4 & $73.9^{\text {cd }}$ & $80.9^{\mathrm{c}}$ \\
Poultry by-product meal 1 & $75.1^{\text {cde }}$ & $86.0^{\mathrm{bc}}$ \\
Poultry by-product meal 2 & $76.0^{\text {cde }}$ & $89.9^{\mathrm{bc}}$ \\
Poultry by-product meal 3 & $74.7^{\text {cde }}$ & $84.6^{\mathrm{bc}}$ \\
Poultry by-product meal 4 & $76.7^{\mathrm{de}}$ & $92.9^{\mathrm{b}}$ \\
Poultry by-product meal 5 & $75.9^{\text {cde }}$ & $88.5^{\mathrm{bc}}$ \\
Poultry by-product meal 6 & $76.7^{\text {de }}$ & $93.2^{\mathrm{b}}$ \\
SEM & $75.2^{\text {cde }}$ & $86.6^{\mathrm{bc}}$ \\
\hline
\end{tabular}

aCalculated by difference from apparent $\mathrm{CP}$ digestibility of urea control.

$b, c, d$, eM eans within a column with different superscripts differ ( $P$ $<.05)$.

tial amino acids may be due to preferential bacterial degradation of nonessential amino acids and nucleic acids in the rumen. Although Weakley et al. (1984) and Goedeken et al. (1990) reported that amino acid profiles were not altered extensively during in situ incubation, this work agrees with that of Varvikko (1986) and Crooker et al. (1981), who reported certain amino acids were more resistant to degradation than others. Amino acid concentrations before incubation were poorly correlated to amino acid concentrations after incubation (Table 6), with the exception of methionine, isoleucine, and lysine, which were highly correlated ( $r=.97, .75$, and .64, respectively, $\mathrm{P}<.05)$. These data indicate that the amino acid profile of dietary MBM and PBM protein before digestion was different from the amino acid profile of ruminal escape protein.

Digestion Study. Protein sources differed $(P<.05)$ in apparent diet $\mathrm{CP}$ and true supplemental $\mathrm{CP}$ digestibilities (Table 7). True supplemental CP digestibilities, calculated by difference from the unsupplemented control, ranged from $95.4 \%$ for SBM to $79.1 \%$ for one MBM source. True CP digestibilities for MBM and PBM sources averaged $87.0 \%$, which is similar to the true CP digestibility of $86.4 \%$ for MBM calculated by Loerch et al. (1983) from duodenal and ileal flow. Escape protein and ash content were poorly correlated to digestibility $\left(\mathrm{R}^{2}=.27\right.$ for escape and $\mathrm{R}^{2}=$ .12 for ash), suggesting that neither is related to $\mathrm{CP}$ digestibility in lambs. Variation in CP digestibility of MBM and PBM, like feather meal, is likely influenced by differences in rendering time and temperature (Aderibigbe and Church, 1983). The content of poorly digestible hair, feathers, and collagen in MBM and PBM may also reduce CP digestibility (Knabe et al., 1989). Overheating during processing and inclusion of hair, feathers, and collagen has been blamed for reduced $\mathrm{CP}$ digestibility, and these are likely the causes of variation in CP digestibility among these products.

Growth Trials. Steers consuming MBM and PBM treatments gained faster $(P<.05)$ than steers fed the urea diet (Table 8). Intake was similar within trial because all animals were fed at an equal percentage of $B W$. Differences in gain would therefore be due to the ruminal escape protein supplied by MBM and PBM sources. Results from the three growth trials were pooled because efficiency of protein utilization was similar $(P>.30)$ for replicated treatments. The three trials were designed to be similar: similar cattle selected from a herd of 800 , feedstuffs used were from

Table 8. Daily gain and dry matter intake of steers fed urea, meat and bone meal, or poultry by-product meal supplements ${ }^{a}$

\begin{tabular}{|c|c|c|c|c|c|c|}
\hline \multirow[b]{2}{*}{ Item } & \multicolumn{2}{|c|}{ Trial 1} & \multicolumn{2}{|c|}{ Trial 2} & \multicolumn{2}{|c|}{ Trial 3} \\
\hline & $\begin{array}{l}\mathrm{ADG}, \\
\mathrm{kg} / \mathrm{d}\end{array}$ & $\begin{array}{l}\text { DMI, } \\
\% \text { BW }\end{array}$ & $\begin{array}{l}\mathrm{ADG}, \\
\mathrm{kg} / \mathrm{d}\end{array}$ & $\begin{array}{l}\text { DMI, } \\
\% \text { BW }\end{array}$ & $\begin{array}{l}\mathrm{ADG}, \\
\mathrm{kg} / \mathrm{d}\end{array}$ & $\begin{array}{l}\text { DMI, } \\
\% \text { BW }\end{array}$ \\
\hline Urea & $.35^{\mathrm{b}}$ & 2.1 & $.43^{\mathrm{b}}$ & 2.3 & $.23^{\mathrm{b}}$ & 2.1 \\
\hline Meat and bone meal 1 & $.41^{\mathrm{bc}}$ & 2.1 & - & - & - & - \\
\hline Meat and bone meal 2 & $.40^{\mathrm{bc}}$ & 2.1 & - & - & - & - \\
\hline Meat and bone meal 3 & $.43^{\mathrm{bc}}$ & 2.1 & - & - & - & - \\
\hline Meat and bone meal 4 & - & - & - & - & $.31^{\mathrm{bc}}$ & 2.1 \\
\hline Poultry by-product meal 1 & $.50^{c}$ & 2.1 & $.57^{\mathrm{c}}$ & 2.3 & - & - \\
\hline Poultry by-product meal 2 & - & - & $.57^{\mathrm{c}}$ & 2.3 & - & - \\
\hline Poultry by-product meal 3 & - & - & $.58^{\mathrm{c}}$ & 2.3 & - & - \\
\hline Poultry by-product meal 4 & - & - & $.63^{\mathrm{c}}$ & 2.3 & $.37^{c}$ & 2.1 \\
\hline Poultry by-product meal 5 & - & - & - & - & $.36^{\mathrm{c}}$ & 2.1 \\
\hline Poultry by-product meal 6 & - & - & - & - & $.38^{\mathrm{c}}$ & 2.1 \\
\hline SEM & .04 & - & .04 & - & .03 & - \\
\hline
\end{tabular}

aExpressed as the average of levels fed.

$b$, Values within a column with unlike superscripts differ $(P<.05)$. 
Table 9. Protein efficiency of test proteins

\begin{tabular}{lc}
\hline \hline Item & $\begin{array}{c}\text { Protein } \\
\text { efficiency }\end{array}$ \\
\hline Meat and bone meal 1 & $.61^{\mathrm{b}}$ \\
Meat and bone meal 2 & $.70^{\mathrm{b}}$ \\
Meat and bone meal 3 & $.76^{\mathrm{b}}$ \\
Meat and bone meal 4 & $.79^{\mathrm{bc}}$ \\
Poultry by-product meal 1 & $1.12^{\mathrm{bc}}$ \\
Poultry by-product meal 2 & $1.15^{\mathrm{bc}}$ \\
Poultry by-product meal 3 & $1.19^{\mathrm{bc}}$ \\
Poultry by-product meal 4 & $1.55^{\mathrm{c}}$ \\
Poultry by-product meal 5 & $1.12^{\mathrm{bc}}$ \\
Poultry by-product meal 6 & $1.54^{\mathrm{c}}$ \\
SEM & .25 \\
\hline
\end{tabular}

${ }^{a}$ Calculated as $\mathrm{kg}$ of gain above urea control per $\mathrm{kg}$ of natural protein above control.

$b, c$ Means with different superscripts differ $(P<.10)$.

the same batch, diets were similar, the same facilities were used, and trial lengths were equal. The urea control diet served as an internal standard, and, even though daily gains differed among trials (.23 to .43 kg/ $\mathrm{d}$ for the urea controls), the gains of by-productsupplemented calves relative to the urea were the values used to calculate protein efficiency values. For example, the average gain response to by-products was $.16 \mathrm{~kg} / \mathrm{d}$ in Trial 2 and $.13 \mathrm{~kg} / \mathrm{d}$ in Trial 3, even though urea control gains varied from .43 to $.23 \mathrm{~kg} / \mathrm{d}$ (Table 8). After combining data across trials, protein efficiency values from the 10 by-products differed among sources ( $P<.10$; Table 9 ), ranging from .61 to 1.55 .

Although escape protein was related to protein efficiency (Table 10), the relationship was negative. An increase in escape protein increases the supply of amino acids to the animal; the quality of this amino acid supply determines how closely it complements microbial protein in meeting an animal's amino acid requirements. Regression of amino acid supply on protein efficiency indicated that most amino acids

Table 10. Regression on protein efficiency

\begin{tabular}{llc}
\hline \hline Item & $\mathrm{R}^{2}$ & Slope \\
\hline $\mathrm{N}$ escape & .75 & -.05 \\
Ash & .45 & -.03 \\
$\mathrm{~N}$ digestibility & .20 & .03 \\
Arginine & .59 & -.50 \\
Cystine & .45 & -1.22 \\
Histidine & .00 & .09 \\
Isoleucine & .11 & .95 \\
Leucine & .13 & -.48 \\
Lysine & .00 & .06 \\
Methionine & .40 & 1.95 \\
Phenylalanine & .02 & -.34 \\
Threonine & .04 & -.51 \\
Valine & .46 & -1.30 \\
Tryptophan & .03 & 2.42 \\
\hline
\end{tabular}

were either poorly correlated to protein efficiency or had a negative slope (Table 10). Methionine, however, was moderately correlated $\left(R^{2}=.40\right)$ to protein efficiency with a positive slope. This suggests that as the level of metabolizable methionine increased in MBM and PBM products, protein efficiency also increased.

During periods of rapid growth, microbial protein production is not sufficient to meet an animal's protein requirements (K lopfenstein et al., 1978). The value of an escape protein source then becomes its ability to complement microbial amino acid production to meet an animal's amino acid requirements. Several researchers have reported that ruminal microbial protein is limiting in methionine and lysine (Nimrick et al., 1970; Fenderson and Bergen, 1975; Richardson and Hatfield, 1978). Like blood meal, MBM is a good source of lysine. However, MBM may contain between 50 and 65\% collagen (E astoe and Long, 1960), which is devoid of tryptophan and low in methionine (Atkinson and Carpenter, 1970).

\section{Implications}

Meat and bone meals and poultry by-product meals are variable in escape protein, ash content, and crude protein digestibility. Twelve-hour in situ escape protein and crude protein digestibility alone are poor indicators of protein efficiency in steers gaining 23 to $.63 \mathrm{~kg} / \mathrm{d}$. Although meat and bone meals and poultry by-product meals improved average daily gain of growing steers relative to urea, differences in protein efficiency seemed to be related to the amount of metabolizable methionine supplied by each product.

\section{Literature Cited}

Aderibigbe, A. O., and D. C. Church. 1983. Feather and hair meals for ruminants. I. Effect of degree of processing on utilization of feather meal. J. Anim. Sci. 56:1198-1207.

AOAC. 1975. Official Methods of Analysis (12th Ed.). Association of Official Analytical Chemists, Washington, DC.

Atkinson, J., and K. J . Carpenter. 1970. Nutritive value of meat meals. I. Possible growth depressant factors. J . Sci. Food Agric. 21:360-365.

Batterham, E. S., and R. E. Darnell. 1986. Effect of pressure and temperature on the availability of lysine in meat and bone meal as determined by slope-ratio assays with growing pigs, rats, and chicks and by chemical techniques. Br. J. Nutr. 55: 441-453.

Blasi, D. A., T. J . Klopfenstein, J . S. Drouillard, and M. H. Sindt. 1991. Hydrolysis time as a factor affecting the nutritive value of feather meal and feather meal-blood meal combinations for growing calves. J. Anim. Sci. 69:1272-1278.

Crooker, B. A., R. D. Shanks, J. H. Clark, and G. C. Fahey. 1981. Effects of ruminal exposure upon the amino acid profile of typical feedstuffs. J. Anim. Sci. 53(Suppl. 1):391 (Abstr.).

Eastoe, J . E., and J . E. Long. 1960. The amino acid composition of processed bones and meat. J. Sci. Food Agric. 11:87-92.

Fenderson, C. L., and W. G. Bergen. 1975. An assessment of essen- 
tial amino acid requirements of growing steers. J. Anim. Sci. 41:1759-1766.

Gibb, D., T. Klopfenstein, and M. Sindt. 1991. Feather meal and meat and bone meal combinations. Nebr. Beef Cattle Rep. MP 59:22-24.

Goedeken, F. K., T. J . Klopfenstein, R. A. Stock, and R. A. Britton. 1990. Hydrolyzed feather meal as a protein source for growing calves. J. Anim. Sci. 68:2945-2953.

Klopfenstein, T., R. Stock, and R. Britton. 1985. Relevance of bypass protein to cattle feeding. Prof. Anim. Sci. 1:27-31.

Klopfenstein, T., J. Waller, N. Merchen, and L. Peterson. 1978. Distillers grains as a naturally protected protein for ruminants. Proc. Distillers Feed Res. Counc. 33:38-45.

Knabe, D. A., D. C. LaRue, E. J . Gregg, G. M. Martinez, and T. D. Tanksley, J r. 1989. Apparent digestibility of nitrogen and amino acids in protein feedstuffs by growing pigs. J . Anim. Sci. 67:441-458.

Leibholz, J . 1979. Meat meal in the diet of the early-weaned pig. III. Meat meal quality and the processing of meat meals. Anim. Sci. Technol. 4:53-61.

Lewis, A. J ., P. J . Holden, R. C. Ewan, and D. R. Zimmerman. 1976. An automated fluorometric method for the measurement of tryptophan in plasma. J. Agric. Food Chem. 24:1081-1083.

Loerch, S. C., L. L. Berger, S. D. Plegge, and G. C. Fahey, J r. 1983. Digestibility and rumen escape of soybean meal, blood meal, meat and bone meal and dehydrated alfalfa nitrogen. J. Anim. Sci. 57:1037-1047.
Nimrick, E., E. E. Hatfield, J . Kaminski, and F. N. Owens. 1970. Quantitative assessment of supplemental amino acid needs for growing lambs fed urea as the sole nitrogen source. J. Nutr. 100:1293-1300.

Richardson, C. R., and E. E. Hatfield. 1978. The limiting amino acids in growing cattle. J. Anim. Sci. 46:740-745.

SAS. 1985. SAS User's Guide: Statistics. SAS Inst. Inc., Cary, NC.

Steel, R.G.D., and J . H. Torrie. 1980. Principles and Procedures of Statistics: A Biometrical Approach (2nd Ed.). McGraw-Hill Publishing Co., New York.

Stock, R., N. Merchen, T. Klopfenstein, and M. Poos. 1981. Feeding value of slowly degraded proteins. J . Anim. Sci. 53:1109-1119.

Varvikko, T. 1986. Microbially corrected amino acid composition of rumen-undegraded feed protein and amino acid degradability in the rumen of feeds enclosed in nylon bags. Br. J . Nutr. 56: 131-140.

Weakley, D. C., F. N. Owens, and W. L. Stockland. 1984. Soybean meal digestion in the rumen: Amino acid changes. Okla. Agric. Exp. Stn. MP 116:179-184.

Wilkerson, V. A., T. J . Klopfenstein, R. A. Britton, R. A. Stock, and P. S. Miller. 1993. Metabolizable protein and amino acid re quirements of growing cattle. J. Anim. Sci. 71:2777-2784.

Wilkerson, V. A., T. J. Klopfenstein, and W. W. Stroup. 1995. A collaborative study of in situ forage protein degradation. J. Anim. Sci. 73:583-588. 